\title{
Effectiveness of dredging and drains' treatment on water quality of Rosetta branch
}

\author{
Mohie Eldin M. Omar ${ }^{1,2^{+*}}$, Mohamed A. Ghareeb ${ }^{3^{*}}$, Shaimaa El Sherbini ${ }^{3^{*}}$ \\ ${ }^{1}$ National Water Research Center (NWRC), Egypt \\ ${ }^{2}$ International Center of Agricultural Research in the Dry Areas (ICARDA), Egypt \\ ${ }^{3}$ Nile Research Institute, Egypt \\ "These authors contributed equally to this work.
}

\begin{abstract}
Rosetta Branch of Nile River in Egypt receives drainage water from five agricultural drains deteriorating its water quality. Since the branch is used for irrigation and municipal purposes, its water quality should be enhanced. Hence, the current paper aimed at providing the most effective intervention to improve the branch water quality. Preventing drainage disposal was excluded due its significance to downstream users. The paper investigated the impacts of drains' treatment and branch dredging on hydrodynamics and water quality. The branch was numerically simulated using HECRAS model, and calibrated using measured water levels and quality parameters. The paper selected constructed wetlands as the most suitable method for drainage treatment based on conditions of study area. SUBWET model predicted optimal designs of wetlands achieving the desired treatment efficiency. SUBWET model was calibrated with experimental wetlands at Delta Barrage. Results showed that $1-\mathrm{m}$ dredging dropped water surface elevations by 22 to $50 \mathrm{~cm}$. Dredging had no significant changes in the backwater zone of Edfina Barrage at the branch end except for the maximum flow case. Simulation of dissolved oxygen and ammonium showed that dredging and treatment improved water quality. Drains' treatment by constructed wetlands with selected designs was much more effective than dredging.
\end{abstract}

Keywords: Drainage treatment, Dredging, HEC-RAS, Rosetta Branch, SUBWET

\section{Introduction}

Egypt is as an arid country that depends on the Nile River providing $93 \%$ of the country's conventional water resources [1]. Rosetta Branch of Nile River has a total length of $256 \mathrm{~km}$ from the Delta Barrage to its disposal to the Mediterranean Sea. It receives drainage water of five agricultural drains transporting their water from intensive drainage networks. Many studies showed the negative impacts of drainage water disposal on the water quality of Rosetta Branch [2-4]. The deterioration of branch water quality is one of the most serious environmental threats to public health and environment in Egypt, as the branch water is the main source for irrigation, municipal and industrial purposes in the western side of Nile Delta. Therefore, proper, science-based, and implementable interventions should be provided to decision makers.

Worldwide, efforts for water quality monitoring and enhancement within watersheds were exerted. Components of spatial and temporal variation in water quality of Potomac River, USA receiving treated sewage effluent were studied. This study also determined the most effective use of future monitoring resources [5]. Impact of tannery effluents on the Fratta-Gorzone River, Italy was studied through sediment analysis, which showed that the concentrations exceeded national and international sediment quality standards [6]. The study showed that pumping of dilution water from Adige River into the Fratta-Gorzone River did not produce the expected contaminant dilution effect. Groundwater in Indus Delta, Pakistan was analyzed for domestic and irrigation purposes [7]. Analysis results showed the unsuitability of most of the delta's water for drinking and agricultural purposes. Thus, this study recommended that wastewater should be properly treated before its use. In Cilutung watershed in Indonesia, the impact of agricultural land use on the rivers' water quality was also investigated according to water quality indices [8]. The results showed that water quality was affected by land use spatially and rivers' discharge temporally.
This is an Open Access article distributed under the terms of the Creative Commons Attribution Non-Commercial License (http://creativecommons.org/licenses/by-nc/3.0/) which permits unrestricted non-commercial use, distribution, and reproduction in any medium, provided the original work is properly cited.
Received September 20, 2020 Accepted December 15, 2020

${ }^{\dagger}$ Corresponding author

E-mail: mohie.omar@hotmail.com

Tel: +961-1-813303/1

Copyright (C) 2022 Korean Society of Environmental Engineers 
From a number of studies worldwide, it can be concluded that the common policies for surface water quality improvement are either pollutants' prevention and treatment, or dredging of bed sediments [9-11]. The agricultural drainage disposal into Rosetta Branch cannot be prevented, since this water is a huge volume of water covering a significant part of total irrigation demand for downstream users. Treatment of drainage water before disposal into the branch might be one intervention. But, selection of the applicable treatment method for the intensive network of drains in the study area is still a debatable issue. There are no sufficient decentralized treatment systems that can collect all drainage water from the network of subsurface and open drains on the farm level and secondary drains ending up with the five main drains which flow into Rosetta Branch.

In the latest few years, there have been emerging new low-cost methods for reducing the environmental hazards of wastewater. Filters from kaolin clay and jute fibers were manufactured, which can be provided for decreasing chemical parameters from water [12]. Ceramic Filters were also presented for water treatment [13-15]. Waste burial using plasma incinerator reactors are another new method for eliminating the emissions of environmental pollutants [16].

Due to the conditions of irrigation catchments of the five main drains, none of the above interventions are sufficient for enhancing the water quality of Rosetta Branch. Decentralized drainage treatment cannot achieve the full treatment of all drainage water. The current paper emphasizes that the centralized treatment of the five main drains as well as dredging of Rosetta branch are the most proper interventions.

The current paper is focused on constructed wetlands (CWs) as the only effective means for agricultural non-point pollution [16-18], and as the only proper method for treatment of drainage disposing into Rosetta Branch. Dredging of sediments with attached pollutants from aquatic environment has positively impacted the environment [19-21], and therefore, dredging of Rosetta Branch might be also a potential intervention for improving its water quality. According to the authors' knowledge, no studies were found on quantifying the science-based effectiveness of both interventions. Therefore, the main objective of current study is to quantify and compare the effectiveness of drains' treatment and bed dredging on the water quality of Rosetta Branch.

In order to achieve this objective, the current paper provides the methodology based on description of study area, data collection, HECRAS modeling of Rosetta Branch, and SUBWET modeling for selecting designs of CWs. Previous numerical modeling of water quality along Rosetta Branch has shown accurate results compared with field data using a number of models including; Mike11 and HEC-RAS [22, 23]. But nevertheless, the current paper provides the calibration process of the current case. To the authors' knowledge, SUBWET model has never been used for design of CWs under Egypt's conditions. Hence, the current paper conducts the calibration process for SUBWET model by simulating actual constructed wetlands. Then, the paper presented the comparison results between the effectiveness of drains' treatment and dredging. The effect of dredging on the hydrodynamics of Rosetta Branch is also presented. The paper finally provides the conclusion of results and their significance, and accordingly the recommendation of most effective intervention.

\section{Methodology}

\subsection{Study Area}

The Nile River is divided into two branches in the Nile Delta namely; Rosetta and Damietta. Rosetta Branch represents the main freshwater stream, which extends from the Delta Barrage at $30^{\circ} 11^{\prime} 04.4^{\prime \prime} \mathrm{N}$ and $31^{\circ} 07^{\prime} 00.4^{\prime \prime} \mathrm{E}$ for about $256 \mathrm{~km}$ on the western boundary of the Nile Delta. It ends with Edfina barrage at $31^{\circ} 18^{\prime} 22.8^{\prime \prime} \mathrm{N}$ and $30^{\circ} 31^{\prime} 07.9^{\prime \prime}$ E with a distance of $30 \mathrm{~km}$ upstream the Mediterranean Sea. Rosetta Branch has an average width of $180 \mathrm{~m}$ and provides water for agricultural, industrial, domestic, and fishery sectors. The agricultural watershed of study area is served by an intensive drainage network consisting of open and subsurface drains at the farm level, which flow by gravity to secondary drains. There are five main drains namely; El Rahawy, Zaweit El Bahr, El Tahrir, Sabal, and Tala, which collect drainage water from secondary drains and dispose their effluents to Rosetta Branch (Fig. 1). Pollution along the branch mainly originates from these five main drains.

\subsection{Data Collection}

This study required data for numerical simulation of hydrologic characteristics and water quality along Rosetta Branch. Data from the most recent hydrographic survey conducted by the Nile Research Institute (NRI) at the National Water Research Center in May, 2019 were utilized to represent the geometry of the branch. The hydrographic

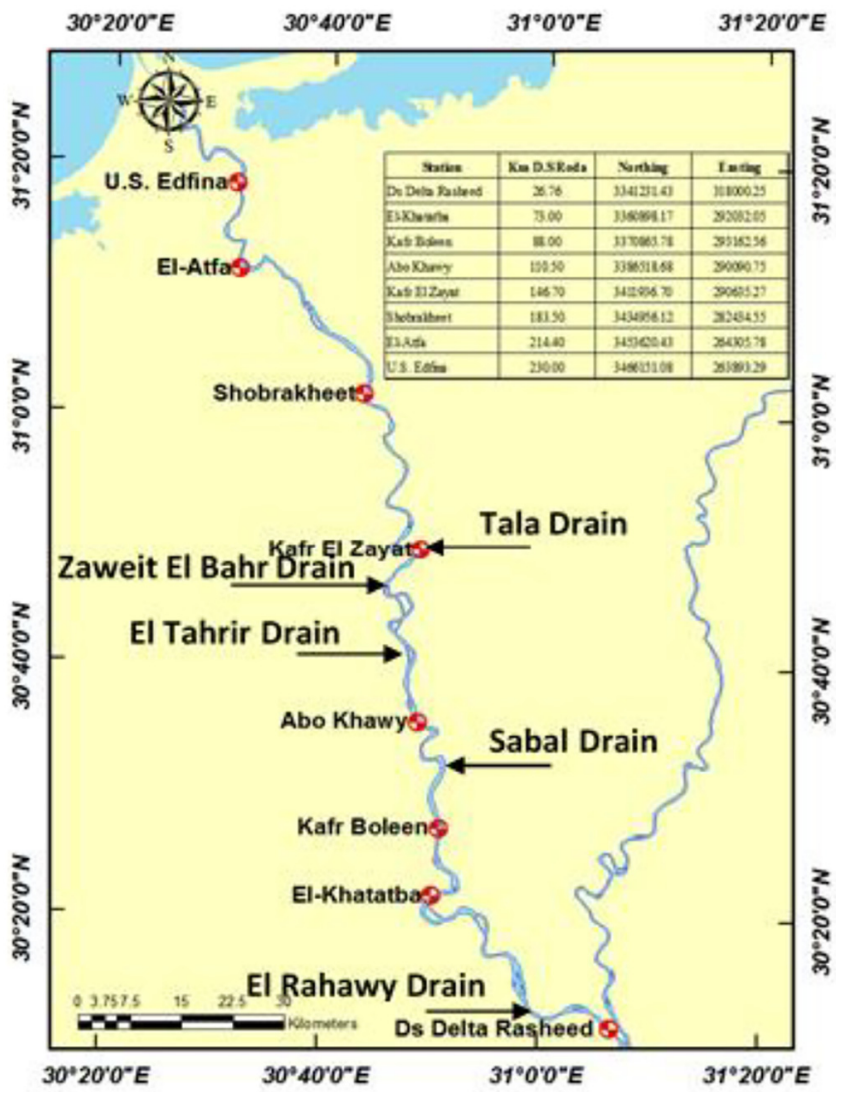

Fig. 1. Rosetta Branch and the five agricultural drains. 
data covered the length between Delta Barrage at $\mathrm{km} 26.500$ to Edfina Barrage at km 230.00 downstream El-Roda gage station. The hydrologic data were collected by NRI for the period from 1997 to 2005 containing water levels at eight gage stations as shown in (Fig. 1), and the inflow discharge D.S. Delta barrage. The hydro-topographic maps for the Nile River developed by the Nile Research Institute were also used to obtain the bank level and to fill any missing bathymetric data. Water quality data at various locations in the branch and for the five drains' effluents were also collected.

\subsection{Modeling Procedures}

Modeling procedures in this research were divided into three stages. The first stage involved the hydrodynamic and water quality simulations along Rosetta Branch under different flow and dredging scenarios using HEC-RAS model. The second stage involved the suggestion of optimal design of CWs for treatment of drains' effluent to Rosetta Branch using SUBWET model. The final stage was to conduct HEC-RAS water quality modeling along the branch with the treated drains by CWs (Fig. 2). The modeling steps were summarized as follows:

i ) Creation and calibration of HEC-RAS model for the hydrodynamic and water quality simulation of Rosetta Branch from Delta Barrage to Edfina Barrage.

ii) Application of HEC-RAS model for prediction of flows, water surface elevations (WSE), and different water quality parameters along the branch under five dredging scenarios, explained in section 2.3.4.

iii) Creation and calibration of SUBWET model for simulation of actual CWs at one research station at the Channel Maintenance Research Institute near Delta Barrage.

iv) Application of SUBWET model to select the optimal designs of CWs for the five drains disposing to Rosetta Branch.

v) Application of HEC-RAS model to predict the water quality parameters along Rosetta Branch in case of treatment of the five drains.

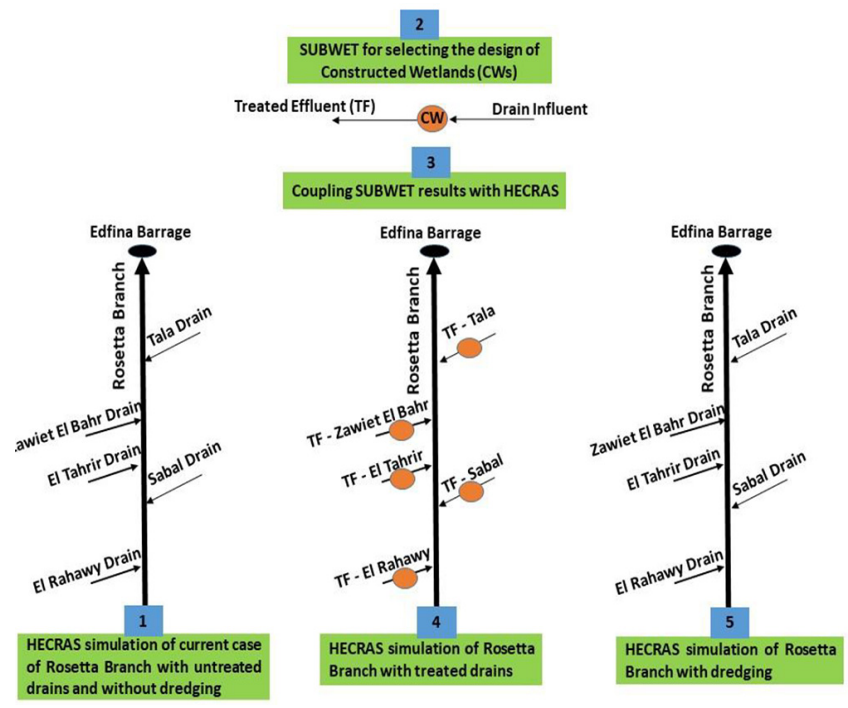

Fig. 2. Overview flowchart of methodology steps.

\subsubsection{HEC-RAS}

HEC-RAS model is used for preforming many river analysis components such as steady flow water surface profile, 1D or 2D unsteady flow simulation, sediment transport computations and water quality analysis. Water surface profile are computed by solving the energy equation for different sections iteratively with the standard step method. The water quality module within HEC-RAS uses the QUICKEST-ULTIMATE explicit numerical scheme at each water quality cell to solve the $1 \mathrm{D}$ advection-dispersion equation. The water quality cells are established between cross sections, and the water quality computational points are located exactly between cross sections pairs. The model simulates the fate and transport of temperature, algae, dissolved oxygen (DO), biological oxygen demand $\left(\mathrm{BOD}_{5}\right)$, organic nitrogen $(\mathrm{OrgN})$, ammonium $\left(\mathrm{NH}_{4}\right)$, nitrite $\left(\mathrm{NO}_{2}\right)$, nitrate $\left(\mathrm{NO}_{3}\right)$, and phosphorus $\left(\mathrm{PO}_{4}\right)$ using the advection-dispersion.

The current study focused on simulating $\mathrm{DO}$ and $\mathrm{NH}_{4}$ as the most important parameter to recognize the water quality status along Rosetta Branch. DO is the main indicator of organic pollution. Its sources are atmospheric aeration and algal photosynthesis, while its losses are algal respiration, sediment oxygen demand, biological oxygen demand, and oxidation of ammonium and nitrite. DO simulation is based on the following equation:

$$
\begin{gathered}
\text { DO }=\mathrm{K}_{2}\left(\mathrm{O}_{\text {sat }}-\mathrm{DO}\right)+\left(\alpha_{3} \mu-\alpha_{4} \rho\right)-\mathrm{K}_{1} \mathrm{BOD}- \\
\frac{\mathrm{K}_{4}}{\mathrm{~d}}-\alpha_{5} \beta_{1} \mathrm{NH}_{4}-\alpha_{6} \beta_{2} \mathrm{NO}_{2}
\end{gathered}
$$

$O_{\text {sat }}=$ dissolved oxygen concentration at saturation value as a function of water temperature (mg/L)

$\alpha_{3}=$ oxygen production per unit algal growth (mg O/mg A)

$\alpha_{4}=$ oxygen uptake per unit algal respired (mg O/mg A)

$\alpha_{5}=$ oxygen uptake per unit NH4 oxidized (mg O/mg A)

$\alpha_{6}=$ oxygen uptake per unit $\mathrm{NO} 2$ oxidized (mg O/mg A)

$K_{1}=$ BOD deoxygination rate $\left(\mathrm{d}^{-1}\right)$

$K_{2}=$ reaeration transfere rate $\left(\mathrm{d}^{-1}\right)$

$K_{4}=$ sediment oxygen demand rate $\left(\mathrm{mg} \mathrm{m}^{2} \mathrm{~d}^{-1}\right)$

$B_{1}=$ rate of ammonia oxidation $\left(\mathrm{d}^{-1}\right)$

$B_{2} \quad=$ rate of nitrite oxidation $\left(\mathrm{d}^{-1}\right)$

$d \quad=$ average channel depth $(\mathrm{m})$

Total ammonia $\left(\mathrm{NH}_{3}\right)$ is considered an important parameter, since it is toxic to aquatic life at concentrations higher than 0.5 $\mathrm{mg} / \mathrm{L}$, and can also cause an excess of algae growth which prevents sunlight from reaching the aquatic life. It is found in water through the decay of organic matter and production of fertilisers, plastics, pharmaceuticals and petrochemicals. The total ammonia was measured as the sum of both un-ionized ammonium $\left(\mathrm{NH}_{3}\right)$ and $\mathrm{NH}_{4}$. Based on $\mathrm{pH}$ and temperatures, the total ammonia values were converted to $\mathrm{NH}_{3}$. Then, the $\mathrm{NH}_{4}$ values were calculated as the difference between total ammonia and $\mathrm{NH}_{3}$. In general, $\mathrm{NH}_{4}$ concentrations are higher with lower $\mathrm{pH}$ and higher temperatures due to the increase of $\mathrm{H}^{+}$ions. $\mathrm{NH}_{4}$, in addition to $\mathrm{NO}_{3}$, are the main inorganic nitrogen compounds. HEC-RAS can simulate $\mathrm{NH}_{4}$, where the nitrogen limitation function is mandatory for the simulation process. It is a unit-less function, and is expressed as:

$$
\mathrm{FN}=\frac{\mathrm{N}_{\mathrm{e}}}{\mathrm{N}_{\mathrm{e}}+\mathrm{KN}}
$$




$$
\begin{aligned}
N_{e}= & \text { effective local concentration of available inorganic nitrogen } \\
& (\mathrm{mg} / \mathrm{L})=\mathrm{NH}_{4}+\mathrm{NO}_{3}
\end{aligned}
$$$$
K N=\text { half-saturation constant for nitrogen }(\mathrm{mg} / \mathrm{L})
$$

$\mathrm{NH}_{4}$ sources are hydrolysis of organic nitrogen and uptake from the benthos, while $\mathrm{NH}_{4}$ sinks are oxidation of ammonium to form nitrite and algal uptake. Accordingly, the model expresses the $\mathrm{NH}_{4}$ sources and sinks as following:

$$
\mathrm{NH}_{4}=\beta_{3} \operatorname{OrgN}+\frac{\sigma_{3}}{\mathrm{~d}}-\beta_{1}\left(1-\exp ^{-\mathrm{KNR} D O}\right) \mathrm{NH}_{4}-\mathrm{F}_{1} \alpha_{1} \mu
$$

$\beta_{3} \quad=$ rate constant for hydrolysis of $\operatorname{OrgN}$ to ammonium $\left(\mathrm{d}^{-1}\right)$

$\beta_{1}=$ rate constant for oxidation of ammonium $\left(\mathrm{d}^{-1}\right)$

$\sigma_{3}=$ benthos source rate $\left(\mathrm{mg} \mathrm{N} / \mathrm{m}^{-2} \mathrm{~d}^{-1}\right)$

$d \quad=$ average channel depth $(\mathrm{m})$ $\mu \quad=$ local groeth rate for algae $\left(\mathrm{d}^{-1}\right)$

$\alpha_{1} \quad=$ fraction of algal biomass that is nitrogen (mg N/mg A)

$K N R=$ first order nitrification inhibition coefficient $(\mathrm{L} / \mathrm{mg})$

$F_{1} \quad=$ fraction of algal uptake (unitless), where it is computed as a function of preference factor for ammonia and nitrate $\left(\mathrm{P}_{\mathrm{N}}\right)$ as following:

$$
\mathrm{F}_{1}=\frac{\mathrm{P}_{\mathrm{N}} \mathrm{NH}_{4}}{\mathrm{P}_{\mathrm{N}} \mathrm{NH}_{4}+\left(1-\mathrm{P}_{\mathrm{N}}\right) \mathrm{NO}_{3}}
$$

For Rosetta Branch, the model was constructed as follows:

i . Bathymetric and land data was interpolated together using ArcGIS to create a raster dataset with pixel size $5 \times 5 \mathrm{~m}$.

ii. The centerline and perpendicular cross-sections along the main stream were created using HEC-GeoRAS tool (Fig. 3(a)).

iii. The geometry file was exported from ArcGIS and imported

File Edit View Bookmanks insert Selection Geoprocessing

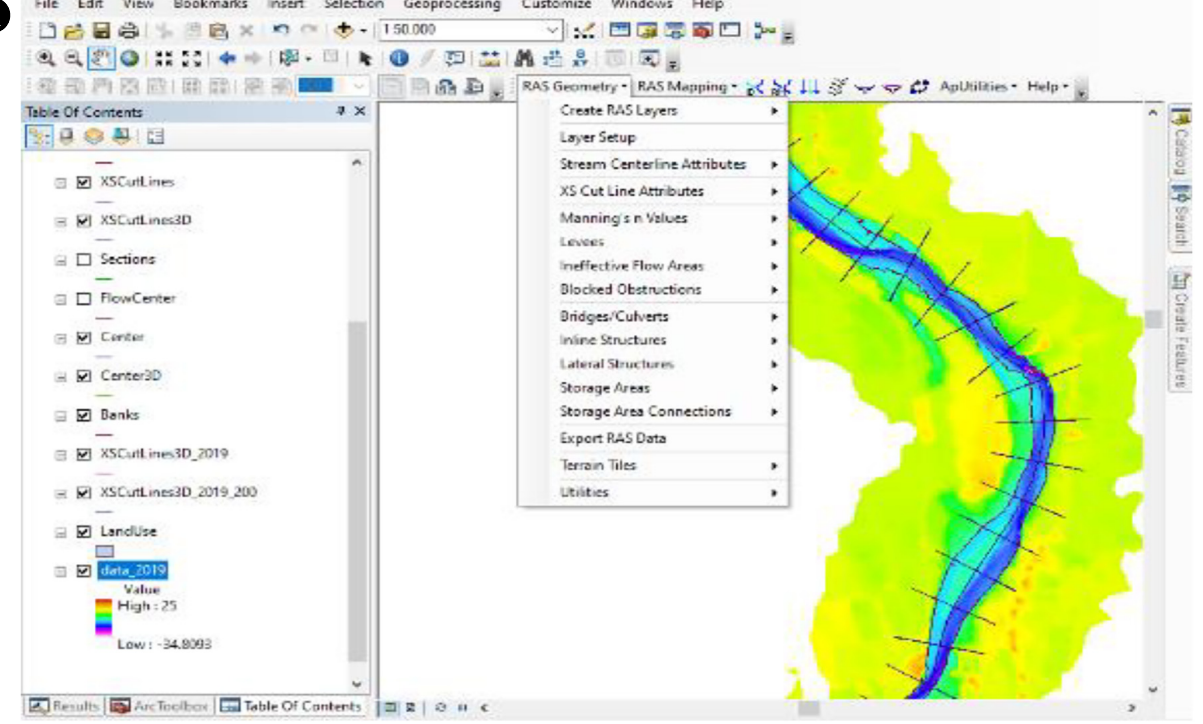

b

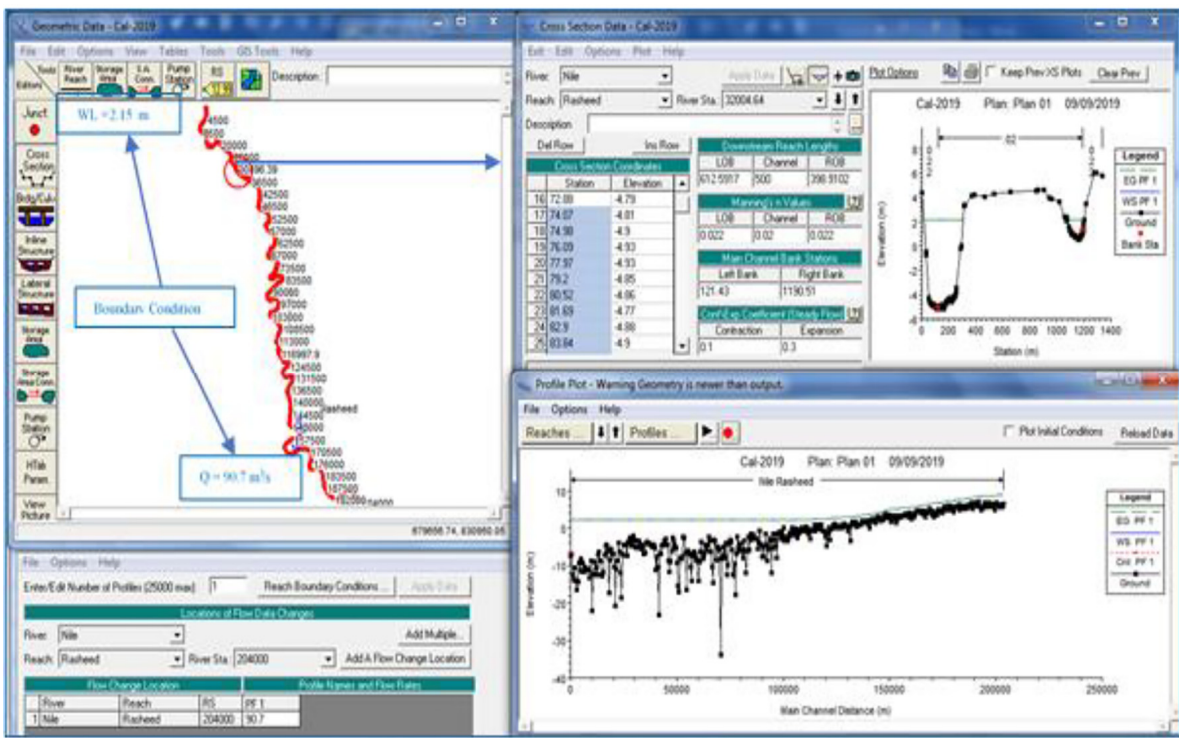

Fig. 3. Model construction for Rosetta Branch. (a) Branch cross sections, (b) Geometry file. 
into HEC-RAS software (Fig. 3(b)) to define the boundary conditions for different flow scenarios.

iv. Different dredging scenarios were applied to the study area as explained in section 2.3.4.

$\mathrm{v}$. The drains' outlet along the centerline were created.

vi. The water quality simulation was done by the water quality module within HEC-RAS.

In the current study, 412 hydraulic cross sections were set for Rosetta Branch, resulting in 412 corresponding water quality cells. In addition, another 20 hydraulic cross sections were set for the five agricultural drains. Various pathways between nutrient parameters were presented in a sub-window included in the water quality data file. This sub-window enabled setting rate constants for reactions within specific ranges.

\subsubsection{Subwet}

The SUBWET model has been developed by UNEP-DTIE-IETC and the Centre for Alternative Wastewater Treatment (CAWT) at Fleming College. The model is used as a predictive tool to determine the size of CWs which can achieve defined removal efficiencies of $\mathrm{BOD}_{5}, \mathrm{NO}_{3}, \mathrm{NH}_{4}, \operatorname{OrgN}$, and $\mathrm{PO}_{4}$. It is based on an alteration to the aerial loading rates, hydraulic retention time (HRT) and the desired level of effluent treatment. The treatment efficiencies of parameters were expressed in the model according to the following equations:

$$
\begin{gathered}
\text { Ammonification }=\operatorname{OrgN} * A C * T A^{(T E M P-20)} \\
\text { Nitrification }=\frac{A M M * N C * I N O X * T N^{(T E M P-20)}}{A M M+M A} \\
\text { Oxidation of organic matter as BOD5 }= \\
B O D_{5} * O C * I N O O * T O^{(T E M P-20)} \\
\text { Denitrification }=\frac{N I T * D C * T D^{(T E M P-20)}}{N I T+M N}
\end{gathered}
$$

$\operatorname{OrgN}$ : concentrations of organic nitrogen in inflowing and outflowing water $(\mathrm{mg} / \mathrm{L})$

$A C \quad$ : ammonification rate coefficient $(\mathrm{L} / \mathrm{d})$

$T A$ : temperature coefficient for ammonification (-)

TEMP : average temperature in centigrade as function of time

$N C \quad$ : nitrification rate coefficient $(\mathrm{L} / \mathrm{d})$

INOX : Michaelis-Menten expression for the influence of oxygen on nitrification rate (-)

TN : temperature coefficient for nitrification (-)

$A M M$ : ammonium concentrations in inflowing and outflowing water $(\mathrm{mg} / \mathrm{L})$

$M A \quad$ : Michaelis-Menten constant for nitrification (mg/L)

$O C \quad$ : oxidation rate coefficient for organic matter, expressed as $\mathrm{BOD}_{5}(\mathrm{~L} / \mathrm{d})$

INOO : Michaelis-Menten expression for oxygen influence on oxidation rate of $\mathrm{BOD}_{5}(-)$

TO : temperature coefficient for oxidation of $\mathrm{BOD}_{5}(-)$

NIT : nitrate concentrations in inflowing and out flowing water $(\mathrm{mg} / \mathrm{L})$

$D C \quad$ : denitrification rate coefficient $(\mathrm{L} / \mathrm{d})$

TD : temperature coefficient for denitrification (-)

MN : Michaelis-Menten constant for denitrification (mg/L)
The SUBWET model inputs were the assumed dimensions and bed slope, average particular matter, hydraulic conductivity, porosity, influent drainage flow to $\mathrm{CW}$, concentrations of $\mathrm{BOD}_{5}$, $\mathrm{NO}_{3}, \mathrm{NH}_{4}, \mathrm{PO}_{4}$ and OrgN, and air temperature. The model parameters were the maximum decomposition rates of $\mathrm{OrgN}$ and organic matter, maximum nitrification and denitrification rates, temperature coefficients of ammonification, nitrification, and denitrification, and maximum plant uptake rates of ammonia, nitrate, and phosphorus. The model outputs were the hydraulic loading rate, CW effluent concentrations, and removal efficiencies of $\mathrm{BOD}_{5}$, $\mathrm{NO}_{3}, \mathrm{NH}_{4}, \mathrm{PO}_{4}$ and OrgN. For each drain, many designs with different dimensions were tested until the optimal design was selected which achieved the desired treatment efficiencies for various parameters.

\subsubsection{Models' calibration}

The calibration process was performed firstly for both the hydrodynamic and water quality simulations of HEC-RAS along Rosetta Branch, and then it was performed for the SUBWET model for design of constructed wetlands under Egyptian conditions. The calibration of HEC-RAS hydrodynamic model was done by changing the manning roughness " $\mathrm{n}$ " along the modelled reach, then comparing WSE at different gauging stations along Rosetta Branch with simulated results. A flow of 13.10 million $\mathrm{m}^{3} / \mathrm{d}$ was taken as a calibration flow input as it represented the average flow during the field survey. The calibration of HEC-RAS water quality model was done by changing the ratio of Chla to algae biomass, fraction of algae biomass, oxygen production and uptake per unit of algae growth, growth limitations, organic settling rates, rates for biological oxidations, decay rates, and sediment oxygen demand. Then, the simulated and measured values of DO and $\mathrm{NH}_{4}$ concentrations were compared at four different locations.

For SUBWET model, the calibration process was undertaken by simulating five actual experimental CWs installed at the Channel Maintenance Research Institute. The location of CWs were at longitude $31^{\circ} 070^{\prime} 2400^{\prime \prime} \mathrm{E}$ and latitude $30^{\circ} 110^{\prime} 5100^{\prime \prime}$ $\mathrm{N}$ in the western bank of the Nile River at Delta Barrages. The CWs had a width of $1 \mathrm{~m}$, length of $4 \mathrm{~m}$, and water depth of 0.7 $\mathrm{cm}$, resulting in a capacity of $2.8 \mathrm{~m}^{3}$. The influent drainage water was transported from Namoul drain in Qualubia governorate. Duckweeds was the main vegetation, which was transported from Eskandar El Mallawia canal in Qualubia governorate. The calibration of SUBWET model was done by changing decomposition rates, coefficients and plant uptake rates. The hydraulic conductivity was chosen in the range from $10^{-9}$ to $10^{-6}$ and the porosity in the range from 33 to $60 \%$ as the clay was dominant in the study area according to Fetter [24]. The calibration process for SUBWET model was undertaken by comparing simulated results with field data for $\mathrm{BOD}_{5}, \mathrm{NO}_{3}, \mathrm{NH}_{4}, \mathrm{OrgN}$ and $\mathrm{PO}_{4}$. Eq. (9) presented the Mean Percentage Relative Error (MPRE) (\%) between numerical results $(\mathrm{N})$ and field results $(\mathrm{F})$ for testing the performance of both models. There has been no specific range of satisfactory performance for water quality modeling.

In the current study, fulfilling requirements of HECRAS modeling of Rosetta Branch is much more complex than SUBWET modeling of CWs. Therefore, the satisfactory performance of HECRAS model 
in the current study could be achieved with MPRE values less than $10 \%$., while it could be achieved with MPRE values less than $5 \%$ for SUBWET model.

$$
\text { MPRE }=\frac{\sum \frac{(\mathrm{N}-\mathrm{F})}{\mathrm{F}} * 100}{\text { Number of results }}
$$

\subsubsection{Modelling scenarios}

Different scenarios were tested to compare the effectiveness of dredging with treating the drains' effluents on water quality status of Rosetta Branch. For investigation of dredging, five scenarios were proposed with an increment of $40 \mathrm{~km}$ from outlet of El Rahawy Drain, as illustrated in Fig. 4(a). The dredging depth was assumed to be $0.50 \mathrm{~m}$ beneath the current bed. Hence the geometry was modified for each scenario by lowering the bathymetric data with $0.50 \mathrm{~m}$, while the bank level remained constant. HEC-RAS geometry file for each scenario was created by HEC-GeoRAS.

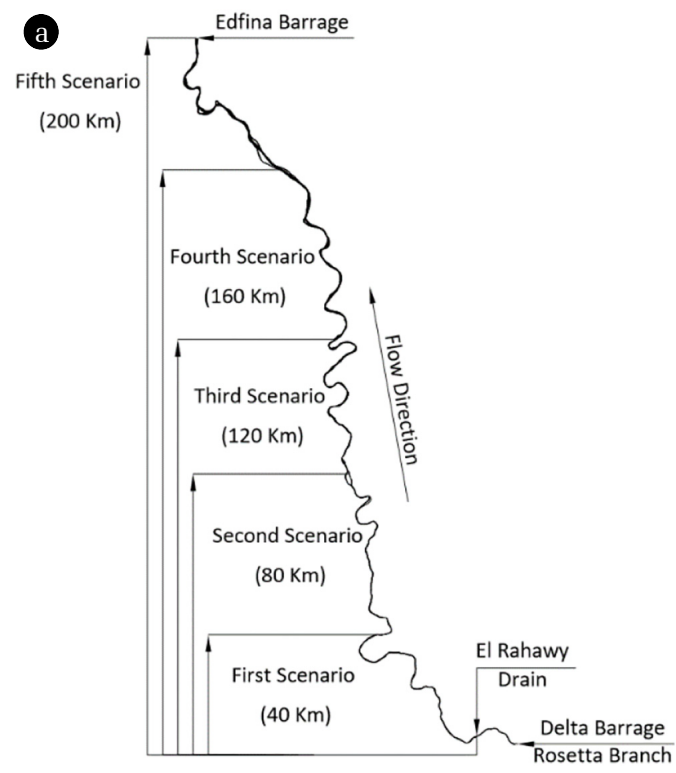

Histogram

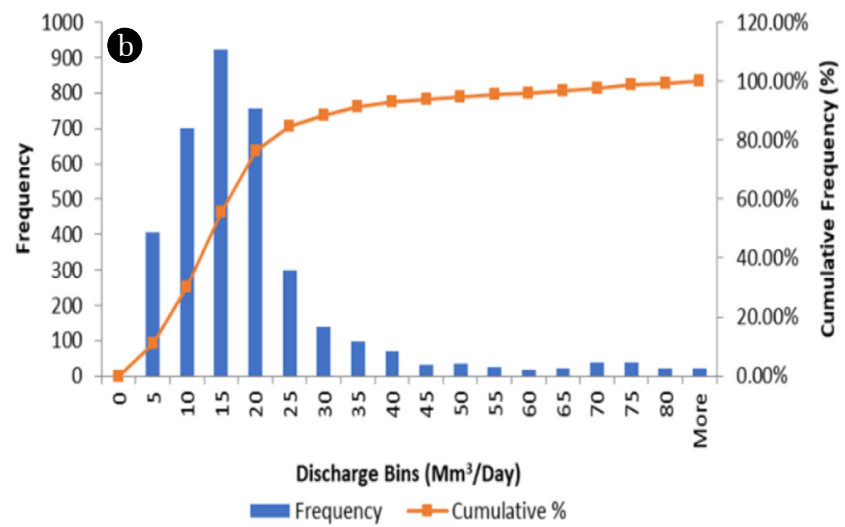

Fig. 4. Dredging and flow scenarios. (a) Dreding scenarios, (b) Flow scenarios.
The effect of dredging on WSE was tested with minimum, maximum and common flow cases, where the flow values were quantified by analyzing the recorded data of flows D.S. Delta Barrage from 1997 to 2007 as shown in the histogram in Fig. 4(b). The bin interval was 5 million $\mathrm{m}^{3} / \mathrm{d}$. The minimum flow was taken at $10 \%$ of discharges, which was found at the bin interval from 0 to 5 million $\mathrm{m}^{3} / \mathrm{d}$ with a value of 4 million $\mathrm{m}^{3} / \mathrm{d}$ and a corresponding water level U.S. Edfina Barrage of $1.9 \mathrm{~m}$. The maximum value was taken at $90 \%$ of discharges corresponding to the bin interval from 25 to million $\mathrm{m}^{3} / \mathrm{d}$ with a value of 25.25 million $\mathrm{m}^{3} / \mathrm{d}$ and a corresponding water level U.S. Edfina Barrage of $2.9 \mathrm{~m}$. The common discharge was taken at the bin interval having the highest frequency, which was found from 10 to 15 million $\mathrm{m}^{3} / \mathrm{d}$ with a value of 13.1 million $\mathrm{m}^{3} / \mathrm{d}$ and a corresponding water level U.S. Edfina Barrage of $1.9 \mathrm{~m}$ as well.

The effect of dredging on water quality was tested for only the fifth scenario for dredging $200 \mathrm{~km}$ (Fig. 4(a)). Within the water quality module, all rate constants for reactions were settled with the same values as the current scenario, except the sediment oxygen demand rate which was reduced from $6 \mathrm{~g} / \mathrm{m}^{2} \mathrm{~d}$ to zero due to dredging of polluted sediments.

For treating the drains' effluents, SUBWET model was used to provide the optimal design of CWs and to predict the resulting constituents' concentrations into the branch. Only one scenario was tested which assumed the treatment of all the five drains. Then, the current constituents were replaced by the predicted constituents' concentrations within the water quality module of HECRAS model, keeping the sediment oxygen demand with a value of $6 \mathrm{~g} / \mathrm{m}^{2} . \mathrm{d}$.

\section{Results and Discussion}

\subsection{Calibration Results}

Fig. 5 shows the simulated and measured water levels along the branch. The calibration results showed a good agreement between measured and simulated values, since both values are almost equal. For calibration of water quality modeling, the concentrations of $\mathrm{DO}$ and $\mathrm{NH}_{4}$ were simulated along the branch and compared with actual field measurements at four locations. MPRE values were $4.45 \%$ and $4.82 \%$ for $\mathrm{DO}$ and $\mathrm{NH}_{4}$, respectively, indicating confident results (Fig. 6).

For calibrating the SUBWET model for estimating the removal efficiencies of actual CWs at the Delta Barrage, the results were compared with the field measurements. The model indicated confident results with MPRE of 1.52, 2.25 and $1.83 \%$ for BOD, $\mathrm{NO}_{3}$ and $\mathrm{NH}_{4}$, respectively.

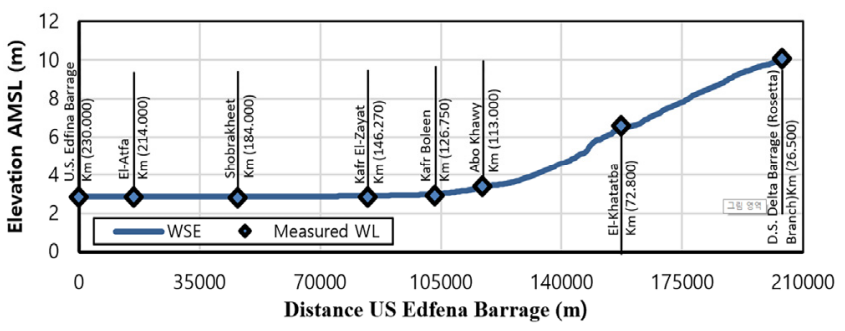

Fig. 5. HEC-RAS hydrodynamic model calibration. 

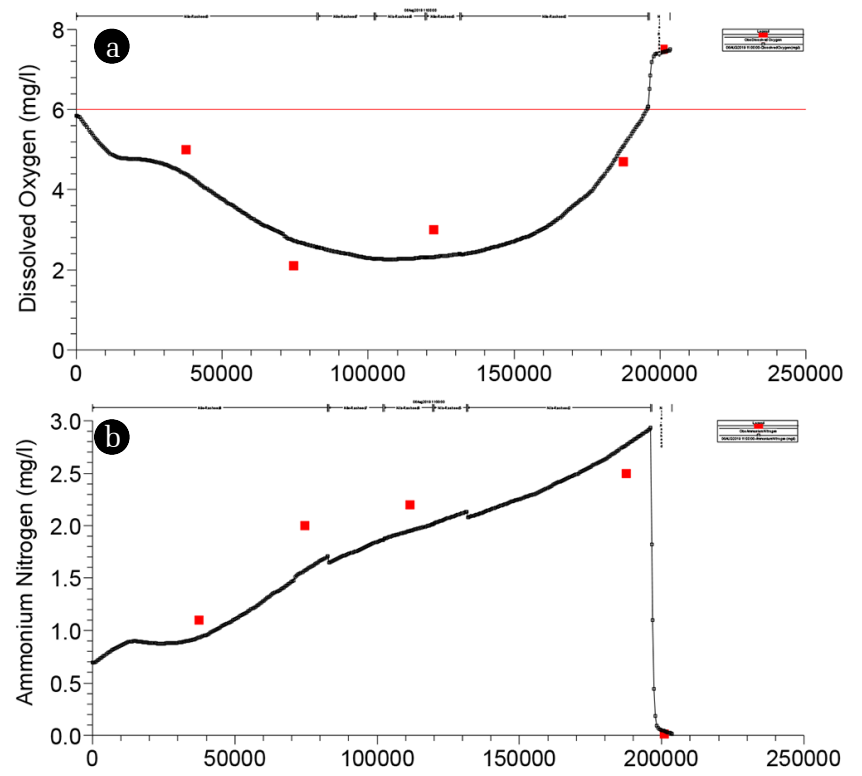

Fig. 6. Calibration of water quality module within HECRAS for simulation of $\mathrm{DO}$ and $\mathrm{NH} 4$ concentrations. (a) $\mathrm{DO}$, (b) $\mathrm{NH}_{4}$.

\subsection{Effect of Dredging on WSE}

Maximum, minimum and common flow conditions were applied for both; the current actual case without dredging and with dredging to investigate the effect of dredging. Fig. 7 shows the simulated WSE for different flow cases. It was clear that the backwater effect of Edfina Barrage extended to 108, 90, $103 \mathrm{~km}$ from U.S. Edfina Barrage for the maximum, minimum and common flow cases, respectively.

The effect of dredging on changing WSE was evaluated for the five proposed dredging scenarios by calculating the drop in WSE for each scenario. Fig. 7 also illustrates the results of applying different dredging scenarios on WSE for different flow cases. The dredging significantly lowered the WSE along the branch. Results showed that the drop in WSE was by approximately $22 \mathrm{~cm}$ at the branch start for all flow cases. The lowering effect differed according to the dredging scenarios. There was no significant change in WSE in the backwater zone except for the maximum flow case.

\subsection{Design of Constructed Wetlands by SUBWET Model}

SUBWET model provided the optimal design for CWs based on a number of factors namely; site characteristics, inlet water quality parameters, and the desired treatment efficiencies. In order to achieve the desired treatment efficiency, the CW width, length, and depth for El Rahawy drain were 50 m, 85 m, 0.5 m, respectively. The corresponding hydraulic rate was $0.047 \mathrm{~m}^{3} / \mathrm{m}^{2}$.d. The CW for Talah drain had dimensions of $30 \mathrm{~m}, 40 \mathrm{~m}$, and $0.5 \mathrm{~m}$ with a corresponding hydraulic rate of $0.041 \mathrm{~m}^{3} / \mathrm{m}^{2}$.d. The CW for Sabal drain had dimensions of $20 \mathrm{~m}, 40 \mathrm{~m}$, and $0.5 \mathrm{~m}$ with a corresponding hydraulic rate of $0.043 \mathrm{~m}^{3} / \mathrm{m}^{2}$.d. The CW for both Zawiet El Bahr and South Tahrir drains had dimensions of $15 \mathrm{~m}, 25 \mathrm{~m}$, and 0.5 $\mathrm{m}$ with a corresponding hydraulic rate of $0.040 \mathrm{~m} / \mathrm{m}^{2} . \mathrm{d}$. The resulting treatment efficiencies were integrated with HECRAS model to test the effectiveness of drains' treatment on the water quality of Rosetta Branch by adding the new concentrations of $\mathrm{BOD}_{5}, \mathrm{DO}$, $\mathrm{NO}_{3}, \mathrm{NO}_{2}, \mathrm{NH}_{4}$, OrgN, OrgP and $\mathrm{PO}_{4}$.

\subsection{Comparing Bed Dredging with Drains' Rreatment by HEC-RAS Model}

The current simulation showed that the $\mathrm{DO}$ value along the branch was lower than the standard value (6 mg/L) according to Law 48/1982 and the Ministerial Decree 92/2013 of the Egyptian Ministry of Water Resources and Irrigation for surface water quality criteria (Fig. 6). There was no constant standard value for $\mathrm{NH}_{4}$ equivalent to values of total ammonia lower than $0.5 \mathrm{mg} / \mathrm{L}$, since the ratio of $\mathrm{NH}_{4}$ to total ammonia is dependent on the $\mathrm{pH}$ and temperature. However, both the simulated and observed $\mathrm{NH}_{4}$ values were equivalent to total ammonia values higher than $0.5 \mathrm{mg} / \mathrm{L}$ along the branch. Both $\mathrm{DO}$ and $\mathrm{NH}_{4}$ values confirmed that the water quality along Rosetta Branch was deteriorated.

In addition, all DO values in the scenario of drains' treatment complied with the DO standard. While, most of DO values in the scenario of bed dredging did not comply with the standard. $\mathrm{NH}_{4}$ values in the scenario of drains' treatment were much lower than the scenario of bed dredging (Fig. 8). In the current case, the minimum
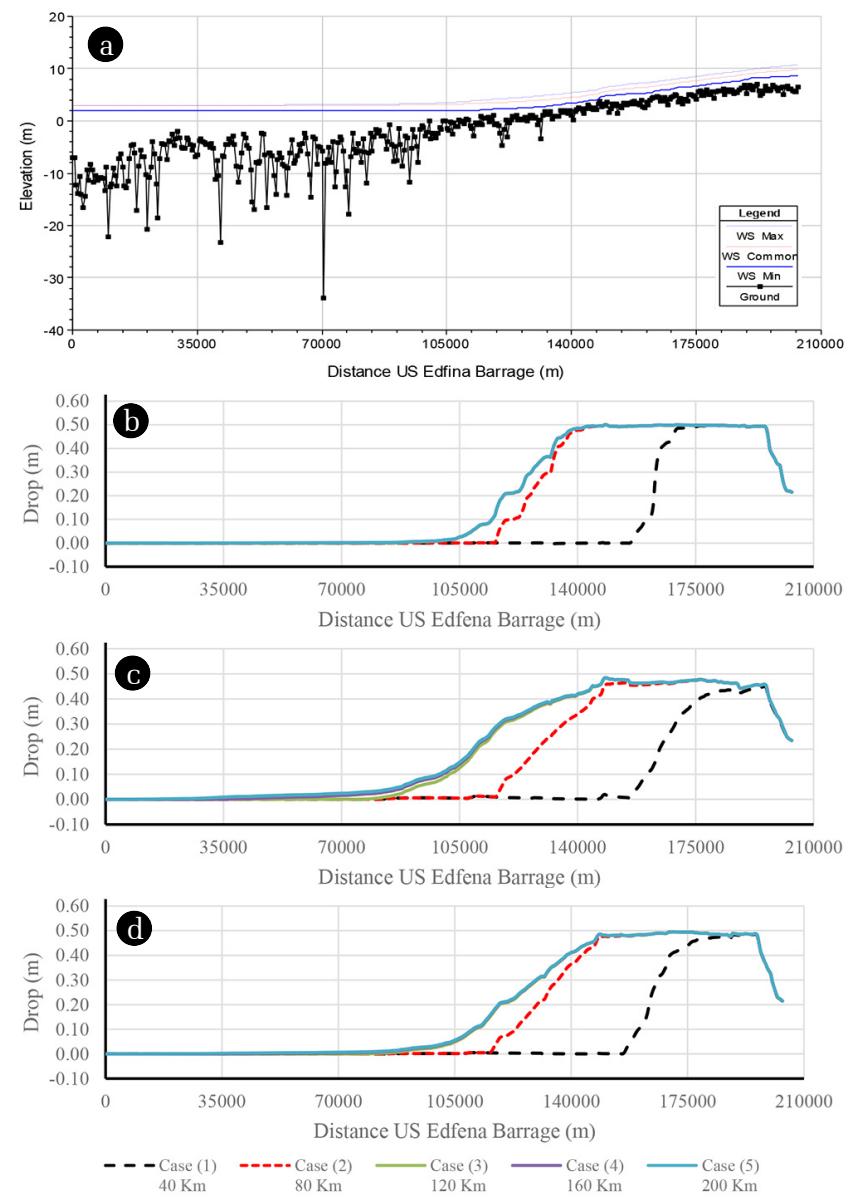

Fig. 7. Water surface elevation and the drop due to dredging. (a) Without dredging, (b) Dredging-minimum case, (c) Dredging-maximum case, (d) Dredging-common case. 

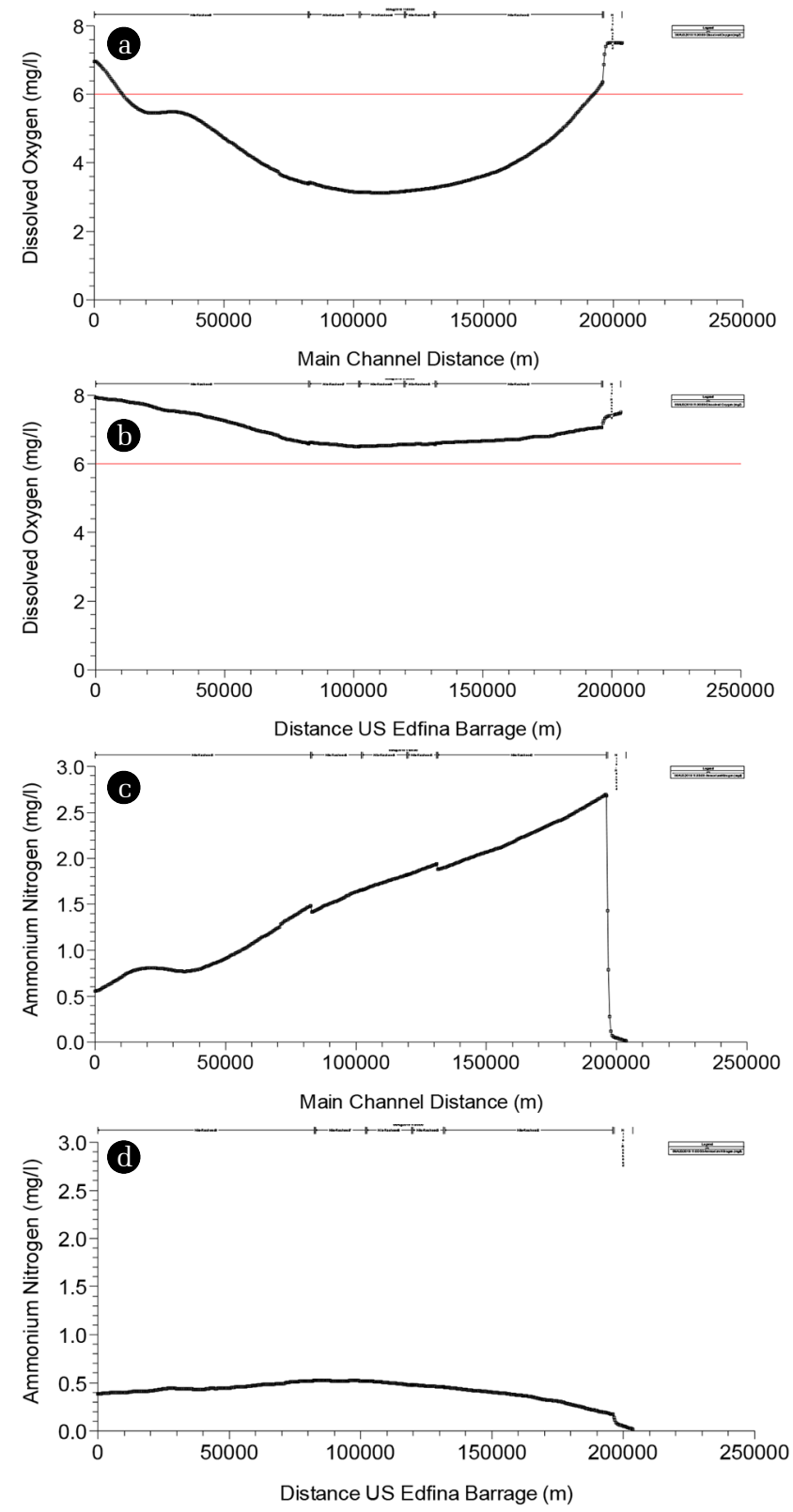

Fig. 8. $\mathrm{DO}$ and $\mathrm{NH}_{4}$ concentrations along Rosetta Branch. (a) DO in case of dredging, (b) DO in case of drains' treatment, (c) $\mathrm{NH} 4$ in case of dredging, (d) $\mathrm{NH}_{4}$ in case of drains' treatment.

DO concentration along Rosetta Branch was $2.42 \mathrm{mg} / \mathrm{L}$, while the maximum concentration was $6.06 \mathrm{mg} / \mathrm{L}$. In case of bed dredging, the minimum DO concentration increased to $3.62 \mathrm{mg} / \mathrm{L}$, and the maximum concentration increased to $7.55 \mathrm{mg} / \mathrm{L}$. In case of drains' treatment, the minimum concentration had an addition increase to a value of $6.42 \mathrm{mg} / \mathrm{L}$, and the maximum value also increased to $7.91 \mathrm{mg} / \mathrm{L}$. NH4 values ranged from 0.69 to $2.95 \mathrm{mg} / \mathrm{L}, 0.55$ to $2.72 \mathrm{mg} / \mathrm{L}$, and 0.31 to $0.62 \mathrm{mg} / \mathrm{L}$ in the current case, in case of dredging, and drains' treatment, respectively.

\section{Discussion}

The calibration process shows a satisfactory performance of HECRAS model for hydrodynamic and water quality simulation of Rosetta Branch. SUBWET model also shows a reliability to simulate constructed wetlands under Egyptian conditions in its first application in Egypt. Both models are used in this study to select the most effective intervention for enhancing the water quality along Rosetta Branch. The prevention of drains' disposal is not investigated in the current paper, due to the high significance of their quantities to downstream users. The current results compare treatment of the five main drains flowing into Rosetta Branch and dredging on the hydrodynamics and water quality of Rosetta Branch.

According the hydrodynamic simulation of Rosetta Brach by HECRAS model, dredging has negative impacts on the WSE, where it drops with a range from $22 \mathrm{~cm}$ to $50 \mathrm{~cm}$ along the branch. Backwater zone of Edfina Barrage will not significantly change, except for the maximum flow case. The water quality simulation and field measurement shows that the current water quality of Rosetta Branch needs to be improved. Both treatment of agricultural drains and dredging of the branch can raise the DO concentrations and reduce the $\mathrm{NH}_{4}$ concentrations. The current paper proves that either intervention can enhance the water quality. DO and $\mathrm{NH}_{4}$ concentrations comply with the water quality standards only in case of drains' treatment, but they do not comply in case of dredging. The current results are in agreement with [22], who used Mike11 model for testing different treatment scenarios, and recommended that reduction of $\mathrm{NH}_{4}$ concentration in the drains by $70 \%$ can improve the current status of the branch water quality.

It is observable that DO concentrations are much higher and $\mathrm{NH}_{4}$ concentrations are much lower than the case of bed dredging. The current paper finds out that the drains' treatment is much more effective than bed dredging. Based on the negative impact of dredging on hydrodynamics and the low impact on water quality, the current paper recommends the drains treatment.

For providing a clear decision making process, the current paper presents the treatment method which is suitable and implementable under the complex conditions of drainage system consisting of intensive secondary drains ending up with the five main drains. In this regard, CWs are the only effective means for agricultural non-point pollution, and accordingly, they can be applicable at the end of the five main drains to guarantee the treatment of all drainage water. The current paper provides the optimal designs of CWs achieving the desired treatment efficiencies using SUBWET model. The CWs dimensions are $50 \mathrm{~m}, 85 \mathrm{~m}, 0.5 \mathrm{~m}$ for El Rahawy drain, $30 \mathrm{~m}, 40 \mathrm{~m}$, and $0.5 \mathrm{~m}$ for Talah drain, $20 \mathrm{~m}, 40 \mathrm{~m}$, and $0.5 \mathrm{~m}$ for Sabal drain, and $15 \mathrm{~m}, 25 \mathrm{~m}$, and $0.5 \mathrm{~m}$ for both Zawiet El Bahr and South Tahrir drains.

The current paper clearly proves that drains' treatment by CWs with the selected dimensions will be the most effective and applicable intervention to achieve the desired water quality of Rosetta Branch.

\section{Conclusions}

(1) The current paper is the first to specifically provide the 
most suitable and effective intervention to enhance the water quality of Rosetta Branch, which its current water quality does not comply with the standards.

(2) Prevention of drains' disposal is not considered, since their huge disposed volumes into the branch are significant in covering the downstream water shortage. Therefore, the current paper is focused on investigating both the drains' treatment and branch dredging.

(3) Based on HECRAS modeling, both interventions can raise the DO concentrations and reduce the $\mathrm{NH}_{4}$ concentrations. The drains' treatment is much more effective than dredging.

(4) The current paper is the first to investigate the impact of dredging on the hydrodynamics of the branch. Dredging has negative effects on the WSE for the maximum, minimum, and common flows, which also adds a preference to drains' treatment.

(5) From the characteristics of study area, the most proper and applicable treatment method for the five drains is CWs. Based on SUBWET model, the current paper provides the design of each CW achieving the desired treatment efficiency.

(6) The current paper recommends applying CWs for the five drains disposing into Rosetta Branch with the selected designs in order to achieve acceptable water quality in the branch.

\section{Author Contributions}

M.M.O. (Associate Professor) conducted the experiments about constructed wetlands and both SUBWET and HEC-RAS modelling, and wrote the manuscript. M.A.G. (Researcher) conducted HEC-RAS modeling, and wrote the manuscript. S.E. (Researcher) conducted HEC-RAS modeling, and wrote the manuscript.

\section{References}

1. Omar M, Moussa A. Water Management in Egypt for Facing the Future Challenges. J. Adv. Res. 2016;7:403-412.

2. Kandil AT, El Saadi AMK, Othman SA. Sensitivity Analysis of Pollution Control of Rosetta Branch during Low Flow Period. Trans. Egypt. Soc. Chem. Eng. 2009;35(4):38-49.

3. El Bouraie M, Yehia MM, Motawea EA, Mohamed GG. Water quality of Rosetta branch in Nile delta, Egypt. J. SUO-Mires Peat. 2011;62:31-37.

4. Ezzat SM, Mahdy HM, Abo-State MA, Abd ESEH, El-Bahnasawy MA. Water quality assessment of River Nile at Rosetta Branch: impact of drains discharge. Middle East J. Sci. Res. 2012;12: 413-423.

5. Jones RC, Kelso DP, Schaeffer E. Spatial and seasonal patterns in water quality in an embayment-mainstem reach of the tidal freshwater Potomac River, USA: a multiyear study. Environ. Monit. Assess. 2008;147:351-375.

6. Giusti L, Taylor A. Natural and anthropogenic contamination of the Fratta-Gorzone river (Veneto, Italy). Environ. Monit. Assess. 2007;134:211-231.

7. Solangi GS, Siyal AA, Siyal P. Analysis of Indus Delta Groundwater and Surface water Suitability for Domestic and
Irrigation Purposes. Civil Eng. J. 2019;5(7):1599-1608.

8. Alvira O, Eko K, Kuswantoro. Assessment of Water Quality in Cilutung Watershed. The $3^{\text {rd }}$ International Conference on Energy, Environmental and Information System (ICENIS 2018), E3S Web Conf. Semarang; 14-15 Aug 2018; Semarang, Indonesia; 2018. p. 6.

9. Cai C. Research Progress in Water Quality Improvement. The 5th Annual International Conference on Material Engineering and Application (ICMEA 2018); 14-16 December 2018; Wuhan, China; 2018:(484)012050. p. 1-5.

10. EHP 2016. Consultation Summary Report: Healthy Waters Management Plan for the Warrego, Paroo, Bulloo and Nebine Basins. Brisbane: Department of Environment and Heritage Protection, Queensland Government; 2016.

11. El Sayed EA, Omar M. Investigating the Constructed Wetlands in the Branches of Bahr Hadous Drain to Reduce its Salinity and Increase Drainage Reuse of El-Salam Canal. Int. J. Appl. 2013;2(5):4-14.

12. Hussein TS, AL-Fatlawi AH. Remove Chemical Contaminants from Potable Water by Household Water Treatment System. Civil Eng. J. 2020;6(2):1534-1546.

13. Kallman EN, Vinka AOC, James AS. Ceramic Filters Impregnated with Silver Nanoparticles for Point-of-Use Water Treatment in Rural Guatemala. J. Environ. Eng. 2011;137(6):407-415.

14. Bulta AL, Geremew AWM. Evaluation of the Efficiency of Ceramic Filters for Water Treatment in Kambata Tabaro Zone, Southern Ethiopia. Environ. Syst. Res. 2019;8(1):1-15.

15. Zereffa EA, Tesfaye BB. Clay Ceramic Filter for Water Treatment. Mater. Sci. Appl. Chem. 2017;34(1):69-74.

16. Abedi-Varaki M, Davtalab M. Site selection for installing plasma incinerator reactor using the GIS in Rudsar county, Iran. Environ. Monit. Assess. 2016;188:353.

17. Stefanakis AI. The Role of Constructed Wetlands as Green Infrastructure for Sustainable Urban Water Management. Sustainability 2019;11(24):6981.

18. Masi F, Rizzo A, Regelsberger M. The role of constructed wetlands in a new circular economy, resource oriented, and ecosystem services paradigm, J. Environ. Manag. 2018;216:275-284.

19. Omar M. Improvement of Detention Ponds with Respect to Salinity [dissertation]. Faculty of Planning Building Environment, Technische Universitaet Berlin; 2010.

20. Aquib SM, Ramchandra NAT, Kishor C, Pai M. Impact of Sand Dredging on Water Quality Parameters of Nethravathi Estuary, Mangaluru. Int. J. Pure App. Biosc. 2016;7(2):335-343.

21. Cappuyns V, Swennen R, Devivier A. Dredged River Sediments: Potential Chemical Time Bombs, Case Study. Water Air Soil Pollut. 2016;171:49-66.

22. Donia N. Investigating the Impacts of Dredging on Improving the Water Quality and Circulation of Lake Mariout via Hydrodynamics. In: Negm A., Bek M., Abdel-Fattah S, Egyptian Coastal Lakes and Wetlands: Part II, Springer eds. Handbook of Environmental Chemistry. 2018. p. 71-103.

23. Mostafa M. Impact of Improving Water Quality at the Tala Drain on the Rosetta Branch Water Quality. J. Environ. Prot. Sci. 2015;6:1149-1157.

24. Fetter CW. Applied Hydrogeology, Macmillan College Publication, New York. 1996; p. 310. 